AperTO - Archivio Istituzionale Open Access dell'Università di Torino

\title{
An unusual case of intestinal leiomyoiositis in a Bernese mountain dog
}

\section{This is the author's manuscript}

Original Citation:

Availability:

This version is available http://hdl.handle.net/2318/1509088

since 2017-05-15T15:09:01Z

Published version:

DOI:10.17236/sat00038

Terms of use:

Open Access

Anyone can freely access the full text of works made available as "Open Access". Works made available under a Creative Commons license can be used according to the terms and conditions of said license. Use of all other works requires consent of the right holder (author or publisher) if not exempted from copyright protection by the applicable law. 


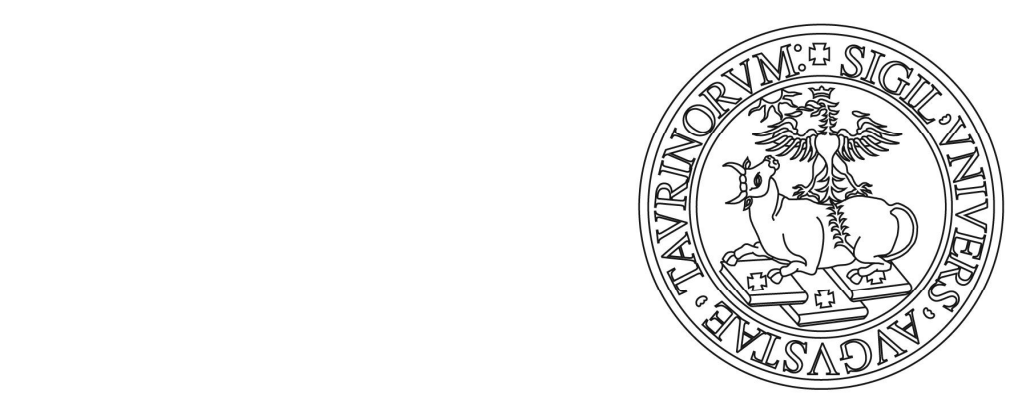

\section{UNIVERSITÀ DEGLI STUDI DI TORINO}

This is an author version of the contribution published on:

Questa è la versione dell'autore dell'opera:

Schweizer Archiv fur Tierheilkunde, 157 (10) ,2015, DOI 10.17236/ sat00038

The definitive version is available at:

La versione definitiva è disponibile alla URL:

http:// www.gstsvs.ch/de/sat/archiv/2015/102015/ wissenschaft-science102015.html?tx_igiplogin_pi2[ipauthfail]=1\#c11187 
An unusual case of intestinal leiomyositis in a bernese mountain dog

P. Gianella ${ }^{1}$, M. Tecilla ${ }^{2}$, C. Bellino ${ }^{1}$, P. Buracco ${ }^{1}$, M. Martano ${ }^{1}$, R. Zanatta ${ }^{1}$, A. Cagnasso $^{1}, A . D^{\prime}$ angelo ${ }^{1}$

${ }^{1}$ Department of Veterinary Sciences, University of Turin, Italy. ${ }^{2}$ Veterinary Science and Publich Health, School of Veterinary M edicine, University of M ilan, Italy

\section{SUM M ARY}

A 1-year-old, female Bernese mountain dog was presented to the Veterinary Teaching Hospital of Turin University with a 3-month history of weight loss, intermittent anorexia, vomiting, constipation, and abdominal distension. Fullthickness biopsies from the stomach, duodenum, jejunum and ileum were collected for histological and immunohistochemical examination. Microscopic lesions displayed severe diffuse degeneration and loss of leiomyocytes, with lymphocytic leiomyositis, fibroplasia, angiogenesis, severe diffuse neuronal atrophy, and ganglioneuritis in the myenteric (Auerbach's) plexus. A diagnosis of chronic idiopatic intestinal pseudo-obstruction was made. Response to immunosuppressive therapy was poor and the dog was humanely euthanized. Unique findings were mononuclear infiltration composed predominantly of B-cell, angiogenesis and weak immunoreactivity for neuron-specific enolase.

Keywords: dog, pseudo-obstruction, intestine, leiomyositis, B-lymphocytes 
Ein 1-jähriger, weiblicher Berner Sennenhund mit einer dreimonatigen Krankheitsgeschichte von Gewichtsverlust, Appetitlosigkeit, intermittierendem Erbrechen, Verstopfung und Blähungen wurde am Tierspital der Universität Turin vorgestellt. Transmurale Darmwandbiopsien aus Magen, Duodenum, Jejunum und lleum wurden für eine histologische und immunhistochemische Untersuchung gesammelt. Die Mikroskopie ergab Läsionen, schwere diffuse Degeneration und Verlust der Leiomyozyten mit lymphatischer Leiomyositis, Fibroplasie, Angiogenese, schwere diffuse neuronale Atrophie und Ganglioneuritis im Plexus myentericus (Auerbach). Eine idiopatische chronische intestinale Pseudoobstruktion wurde somit diagnostiziert. Das Ergebnis der immunsuppressiven Therapie war negativ und der Hund wurde eingeschläfert. Eine mononukleäre Infiltration vorwiegend von B-Zellen sowie eine Angiogenese in Verbindung mit schwacher Immunreaktivität für Neuronspezifische Enolase wurden anhand von Gewebeproben eindeutig festgestellt.

Schlüsselwörter: Hund, Pseudoobstruktion, Darm, Leiomyositis, B-Lymphozyten

\section{Introduction}

Chronic intestinal pseudo-obstruction (CIPO) is a rare gastrointestinal syndrome characterized by impaired intestinal motility that results in clinical signs of bowel obstruction without evidence of mechanical occlusion of the gut lumen. In human medicine, pseudo-obstruction syndrome may be either acute or chronic (Di Lorenzo, 1999). The chronic form has been described in different animal species including dogs (Dvir et al., 2001; Eastwood et al., 2005; Johnson et al., 2007; Vandenberge et al., 2009; Murtagh, 2013). The acute form has been associated with abdominal surgery, peritonitis, hypokalemia, spinal or pelvic trauma, viral enteritis, pancreatitis, intestinal infarction, anticholinergic and opioid therapy (De Giorgio et al., 2011). The chronic form, either congenital or acquired, is characterized by recurrent arrest of intestinal motility. The latter can be associated with neurologic, metabolic, endocrine, paraneoplastic, autoimmune and infectious diseases (De 
Giorgio et al., 2011). In humans, CIPO may involve interstitial cells of Cajal and components of the neuronal or muscular gastrointestinal motility control systems, either alone or in combination; more rarely, it may occur together with mesenchymopathies (De Giorgio et al., 2011). Fibrosis and infiltration of the smooth-muscle fibers of the tunica muscularis by mononuclear cells are the most frequently reported macroscopic lesions of CIPO in the dog (Dvir et al., 2001; Eastwood et al., 2005). Occasional involvement of gastric and bladder musculature was reported (Johnson et al., 2007). The suspicion of CIPO relies on the exclusion of a mechanical basis of subocclusion. A definitive diagnosis rests on full thickness biopsies that can provide clues to the nature of neuromuscular impairment (Knowles, 2009).

\section{Clinical and laboratory examination}

A 1-year-old, female Bernese mountain dog was referred to the Veterinary Teaching Hospital (VTH) of Turin University because of a 3-month history of weight loss, intermittent anorexia and vomiting, constipation and abdominal distension. Symptomatic treatment with antiemetics (maropitant, $60 \mathrm{mg}, \mathrm{PO}, \mathrm{q} 24 \mathrm{~h}$, for 5 days), antibiotics (metronidazole $10 \mathrm{mg} / \mathrm{kg}, \mathrm{PO}, \mathrm{q} 12 \mathrm{~h}$ for 2 weeks in addition to amoxicillinclavulanate $20 \mathrm{mg} / \mathrm{kg}, \mathrm{PO}, \mathrm{q} 12 \mathrm{~h}$ ), disaccharide laxatives (lactulose, $6 \mathrm{ml} \mathrm{PO}, \mathrm{q} 12 \mathrm{~h}$ ), warm water enemas and commercial diets (low-residue-producing diet and hydrolyzed diet) had brought no improvement. Abdominal radiographs performed by the referring veterinarian showed generalized, dilated small bowel loops suggestive of intestinal obstruction. Exploratory celiotomy ruled out mechanical obstruction. The dog was subsequently referred to the VTH. On clinical examination, the dog exhibited mild dehydration, tachycardia, intermittent polypnea and distended abdomen with fluid and gas-filled intestinal loops. Neurological examination was normal. Hematological analysis revealed mild normocytic normochromic nonregenerative anemia $\left(4.43 \times 10^{12} / \mathrm{l}\right.$, normal range 5.7-8.8 $\left.\times 10^{12} / \mathrm{l}\right)$. 
Serum biochemical analysis and serum protein electrophoresis demonstrated a low total protein (46 $\mathrm{g} / \mathrm{l}$, normal range $54-75 \mathrm{~g} / \mathrm{l})$ with low albumin $(21 \mathrm{~g} / \mathrm{l}$, normal range 29-35 g/l) and normal globulin ( $25 \mathrm{~g} / \mathrm{l}$, normal range $25-40 \mathrm{~g} / \mathrm{l})$. Arterial blood gas, urinalysis, pre- and post-prandial bile acids and adrenocorticotrophic (ACTH) stimulation test were within normal limits. Tyroid stimulating hormone (TSH) was normal with decreased tT4 (11.71 nmol/l, normal range 12.87-45.04 nmol/l); a "euthyroid sick syndrome" was suspected. The antinuclear antibody test was negative and the serum Spec CPL®test (IDEXX laboratories) for pancreatic lipase was normal. Thoracic radiographs were unremarkable. Abdominal radiographs and ultrasonography confirmed a generalized, severe distension of the small intestine by gas and fluid. A second celiotomy was performed to collect full-thickness biopsies from the stomach, duodenum, jejunum and ileum.

\section{Histopathologic and immunohistochemical findings}

Tissue samples were fixed in 10\% neutral buffered formalin and routinely processed. Tissue sections $5 \mu \mathrm{m}$ in thickness were stained for histology with haematoxylin and eosin, Masson's trichrome, periodic acid-Schiff (PAS) for histology, and by a standard avidin-biotin peroxidase method for immunohistochemistry. Table 1 lists the primary antibodies utilized. Negative controls consisted of substitution of specific antibodies with an isotype-matched, irrelevant monoclonal antibody or omission of the primary antibody. Histological findings in the stomach included mild gastric submucosal fibrosis with occasional lamina propria infiltration by small mature lymphocytes. Gastric muscularis mucosa, muscular layers and the plexuses were normal. Histological findings in duodenum, jejunum and ileum were similar, with maximal severity in jejunum. The intestinal epithelium of all tracts contained increased numbers of mucous cells. The lamina propria was severely infiltrated by small mature lymphocytes and plasma cells. The lymphatic vessels in the ileum were dilated. Ileal muscularis mucosa was characterized by a moderate infiltrate of 
mature lymphocytes, mild fibrosis and angiogenesis. The most severe changes were observed in the circular and, to a lesser extent, in the longitudinal muscular layers of the small intestine (Fig. 1). Severe atrophy of the circular muscular layer was associated with replacement of the smooth-muscle fibres with angiogenesis, fibroplasia and infiltration by small numbers of mature lymphocytes and occasional plasma cells. The longitudinal muscular layer was replaced by fibrosis, with greatest loss of myocytes observed in the duodenum, the jejunum and, to a lesser degree, the ileum. An abrupt transition between the circular and longitudinal muscular layers was evident in the duodenum and jejunum, often together with haemorrhages. In addition, occasional non-degenerated neutrophils and rare eosinophils were observed. The submucosal (Meissner's) plexus was not visible, while the ganglia of the myenteric (Auerbach's) plexus were characterized by fibrosis and small mature lymphocyte infiltration with neuronal atrophy.

Masson's trichrome evidenced a normal gastric muscular structure. In the duodenum and ileum, the muscularis mucosa was normal in thickness, however, weaker staining intensity and thinning was detected in the jejunum. Overall, there was complete loss of circular musculature, while some areas of the longitudinal layer in the ileum stained in red (Fig. 2). Severe fibrosis extended from or under the muscularis mucosa to the serosal lining of the duodenum and the jejunum and to a lesser extent in the ileum. These findings were confirmed by smooth-muscle actin and desmin stains that demonstrated the almost complete absence of leiomyocytes in the circular and longitudinal layers of the duodenum (Fig. 3).

Neuron Specific Enolase (NSE) identified neurons of the myenteric plexus of Auerbach, while no neurons were found in the myenteric plexus of M eissner. In the duodenum and jejunum, CD20+, CD3- B cell predominated, while T cell represented $15 \%$ or less of the inflammatory lymphoid component. In the ileum, B cells were prevalent in nodular aggregates. In contrast, CD3+, CD20- T cells predominated in 
the jejunum. PAS stain did not demonstrate fungal hyphae but confirmed a severe increased number of mucous cells.

Diagnosis, treatment and outcome

The dog was initially treated with intravenous fluids, metoclopramide (2 mg/ kg/24 hours constant rate infusion), amoxicillin-clavulanate $(20 \mathrm{mg} / \mathrm{kg}, \mathrm{IV}, \mathrm{q} 12 \mathrm{~h}$ ), metronidazole (10 mg/kg, IV, q12h), buprenorphine $(0,01 \mathrm{mg} / \mathrm{kg}, \mathrm{IV}, \mathrm{q} 8 \mathrm{~h})$, ranitidine (2 mg/kg, IV, $\mathrm{q} 12 \mathrm{~h}$ ) and erythromycin (2 mg/ $\mathrm{kg}, \mathrm{PO}, \mathrm{q} 8 \mathrm{~h}$ ). A poor response to treatment was seen. A histopathological diagnosis of severe, diffuse chronic degeneration and loss of leiomyocytes, with lymphocytic leiomyositis, fibroplasia, angiogenesis, severe diffuse atrophy and chronic lymphoplasmacytic ganglioneuritis in the myenteric (Auerbach's) plexus causing CIPO was made. Following the histopathological diagnosis of intestinal leiomyositis an immunosuppressive therapy with prednisone ( $1 \mathrm{mg} / \mathrm{kg}, \mathrm{PO}, \mathrm{q} 12 \mathrm{~h}$ ) was started. However, two weeks later, due to the poor response to treatment and, upon owner request, the dog was humanely euthanized. Necropsy was not permitted.

\section{Discussion}

As compared to previous reports of CIPO in the dog (Dvir et al., 2001; Vandenberge et al., 2009), the distinctive pathological findings in the current case were the extensive angiogenesis, particularly in the circular muscle layer, the low number of inflammatory cells, predominantly of B-cells, and the reduced immunoreactivity for NSE. Moreover, the ganglia of the submucosal plexus were not microscopically visible perhaps because of the severe changes or because of a true aplasia. The inflammation of the myenteric plexus was interpreted as being secondary to the interstitial leiomyositis. Several cases of canine CIPO have been associated with secondary inflammation of the myenteric plexuses (Dvir et al., 2001), however, no 
cases of CIPO due to primary visceral neuropathy have been reported. Furthermore, human neuropathic CIPO is generally not associated with severe muscular lesions like those observed in the current case. The muscular angiogenesis and fibrosis observed here shared common features with human "hollow primary visceral myopathy" characterized by fibrosis and leiomiocyte degeneration (M uñoz-Yagüe et al., 2006). However, the stomach was normal and no information about oesophagus, colon or bladder involvement could be gleaned from the clinical history.

An immune-mediated pathogenesis involving "effector" lymphoid cells has been suggested in both humans and dogs (Vandenberge, 2009), but the low number of inflammatory cells and the abundance of B-lymphocytes reported here seem to contrast partially with this hypothesis. The reason for these unique features is not clear. A dense T-cell infiltrate without fibrosis has been associated with early-stage of disease (Murtagh, 2013), while B-cell infiltrates may represent either a later inflammatory response or a consequence of superficial inflammation. The latter, also observed in this dog, is a frequent secondary finding in CIPO and has been associated with bacterial overgrowth (Connor and Di Lorenzo, 2006). Bacteria or their toxins may also be responsible for a reduction in intestinal NSE immunoreactivity, as has been demonstrated in equine grass sickness (Griffiths et al., 1993).

There is no cure for CIPO and management strategies include a wide array of nutritional and pharmacologic options which are mainly directed to minimize malnutrition, promote gut motility, reduce inflammation and complications of stasis (De Giorgio et al., 2011). Particularly, a variety of prokinetics drugs, eg, erythromycin, metoclopramide, domperidone, neostigmine, serotoninergic agents, prostaglandins and somatostatins analogs have been used with variable results (Di Lorenzo, 1999; Sanger, 2009). In the veterinary literature, except for a recent case 
(Murtagh, 2013), symptomatic and immunosuppressive therapies have been unsuccessfull. The lack of clinical response observed here may have been due to a late diagnosis, as supported by the long history of gastrointestinal signs before presentation. Particularly, as suggested in human medicine, the presence of fibrosis can explain the lack of response to immunosuppressive therapy. (Ginies et al., 1996).

This is the first report to describe leiomyositis with mononuclear cell infiltration predominantly composed of B-lymphocytes, angiogenesis and reduced immunoreactivity for NSE in a dog with CIPO. Since lesions are frequently confined to the muscular layers, full-thickness biopsy is essential for making a definitive diagnosis, while superficial biopsies may delay correct diagnosis.

Aknowledgement: the authors thank Dr. M ichele Hettinger who referred the case.

\section{References}

Connor FL., Di Lorenzo C.: Chronic intestinal pseudo-obstruction: Assessment and M anagement. Gastroenterol. 2006, 130: 29-36.

Di Lorenzo C.: Pseudo-obstruction: current approaches. Gastroenterol. 1999, 116: 980-987.

De Giorgio R., Coliandro R.F., Barbara G., Corinaldesi R., Stanghellini V.: Chronic 
intestinal pseudo-obstruction: clinical features, diagnosis, and therapy. Gastroenterol Clin North Am. 2011, 40: 787-807.

Dvir E, Leisewitz A.L., Van der Lugt J.J.: Chronic idiopathic intestinal pseudoobstruction in an English bulldog. J Small Anim Pract. 2001, 42: 243-247.

Eastwood J.M., M clnnes E.F., White R.N., Elwood C.M., Stock G.: Caecal impaction and chronic intestinal pseudo-obstruction in a dog. J Vet Med A Physiol Pathol Clin Med. 2005, 52: 43-44.

Ginies J., L., Francois H., Joseph M., G., Champion G., Coupris L., LImal J., M.: A curable cause of chronic idiopathic intestinalpsuedo-obstruction in children: idiopathic myositis of the small intestine. J Pediatr Gastroenterol Nutr. 1996, 23: 426-429.

Griffiths I.R., Kyriakides E., Smith S., Howie F., Deary A.W .: Immunocytochemical and lectin histochemical study of neuronal lesions in autonomic ganglia of horses with grass sickness. Equine Vet J. 1993, 25: 446-452.

Johnson C. S., Fales-Williams A. J., Reimer S. B., Lotsikas P. J., Haynes J. S.: Fibrosing gastrointestinal leiomyositis as a cause of chronic intestinal pseudo-obstruction in an 8-month-old dog. Vet Pathol. 2007, 44: 106-109. 
Knowles C.H., De Giorgio R., Kapur R.P., Bruder E., Farrugia G., Geboes K., Lindberg G., M artin J.E., M eier-Ruge W.A., M illa P.J., Smith V.V., Vandervinden J.M., Veress B., Wedel T.: Gastrointestinal neuromuscular pathology: guidelines for histological techniques and reporting on behalf of the Gastro 2009 International Working Group. Acta Neuropathol. 2009, 118: 271-301.

M uñoz-Yagüe M.T., Marín J.C., Colina F., Ibarrola C., López-Alonso G., Martín M .A., Solís-Herruzo J.A.: Chronic primary intestinal pseudo-obstruction from visceral myopathy. Rev Esp Enferm Dig. 2006, 98: 292-302.

Murtagh K.: Successful management of intestinal pseudo-obstruction in a dog. Vet Rec Case Rep, 2013, 1: 1-2.

Sanger G. J.: Translating 5-HT receptor pharmacology. Neurogastroenterol Motil. 2009, 21: 1235-1238.

Vandenberge V., Paepe D., Vercauteren G., Daminet S., Ducatelle R., Chiers K.:

Chronic intestinal pseudo-obstruction in a Bernese M ountain Dog. Vlaams Diergeneeskd Tijdschr, 2009, 78: 117-120.

Corresponding author 
P. Gianella, DVM , PhD, Dipl. ACVIM , Assistant Professor, Department of Veterinary

Sciences, Clinical Section, University of Turin, Largo P. Braccini 2 (ex Via Leonardo Da Vinci 44), 10095 Grugliasco (To) - Italy.

Tel. +39 011-6709074, Fax +39 011-6709083, E-M ail: paola.gianella@ unito.it

Table 1. Antibody panel used on gastrointestinal tissue samples.

\begin{tabular}{|c|l|l|l|}
\hline $\begin{array}{c}\text { Target antigen } \\
\text { actin }\end{array}$ & \multicolumn{1}{|c|}{ Clone } & \multicolumn{1}{|c|}{ Company } \\
\hline $\begin{array}{c}\text { Smooth muscle } \\
\text { Desmin }\end{array}$ & DE-RII & $1: 2000$ & $\begin{array}{l}\text { Dako, Glostrup, } \\
\text { Denmark }\end{array}$ \\
\hline $\begin{array}{c}\text { Neuron Specific } \\
\text { Enolase (NSE) }\end{array}$ & BBS/NC/VI-H14 & $1: 25$ & Novocastra, \\
& & $1: 400$ & $\begin{array}{l}\text { Dewcastle, UK } \\
\text { Deno, Glostrup, }\end{array}$ \\
\hline CD79a & HM-57 & $1: 20$ & $\begin{array}{l}\text { Dako, Glostrup, } \\
\text { Denmark }\end{array}$ \\
\hline CD20 & Rabbit Polyclonal & $1: 40$ & Serotec, \\
& & $1: 10$ & Oxford, UK \\
\hline & & & Neomarkers, \\
& & & \\
\hline & & & CA.S.A. \\
\hline
\end{tabular}




\section{Figure 1}

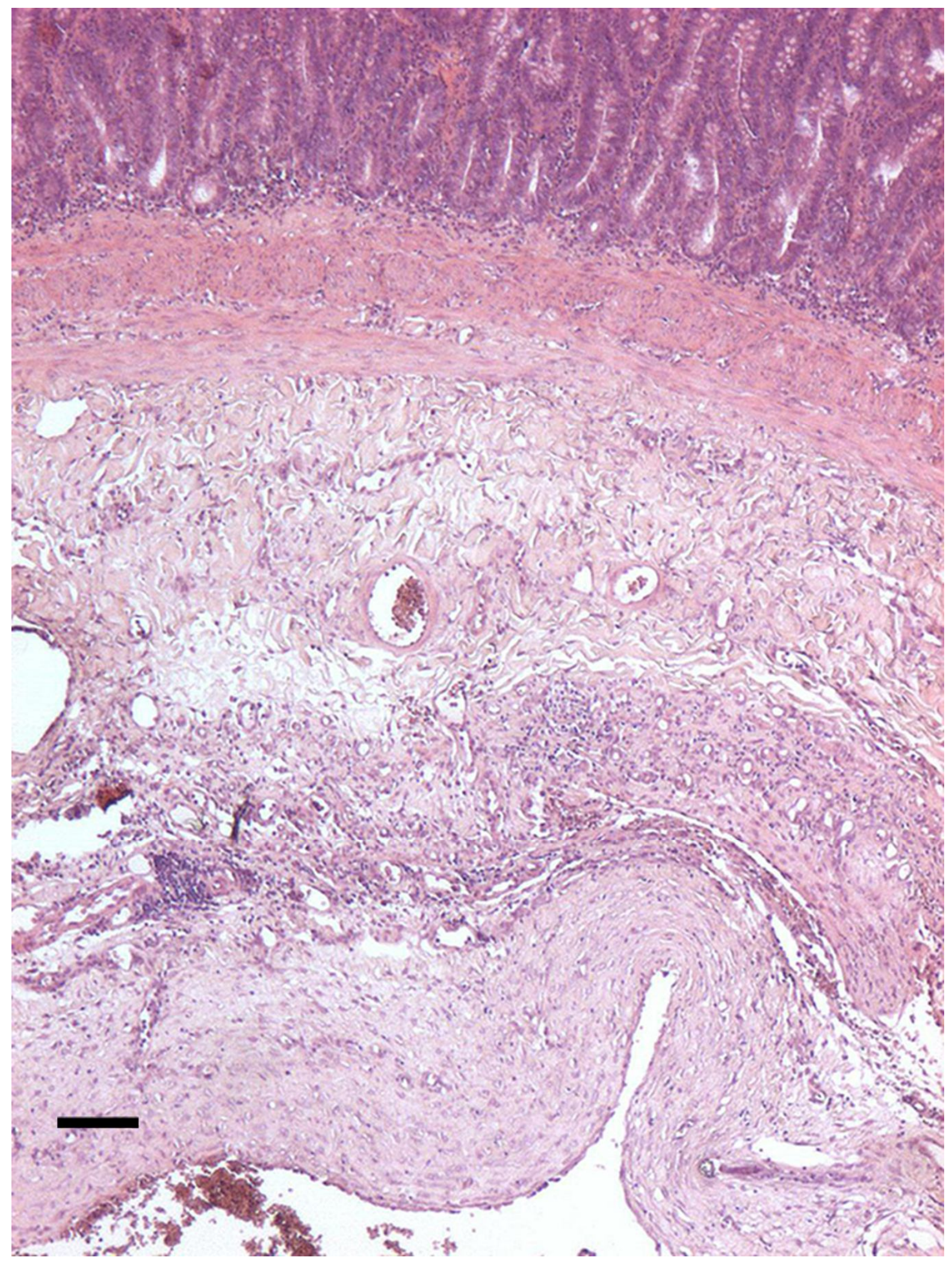


Figure 2

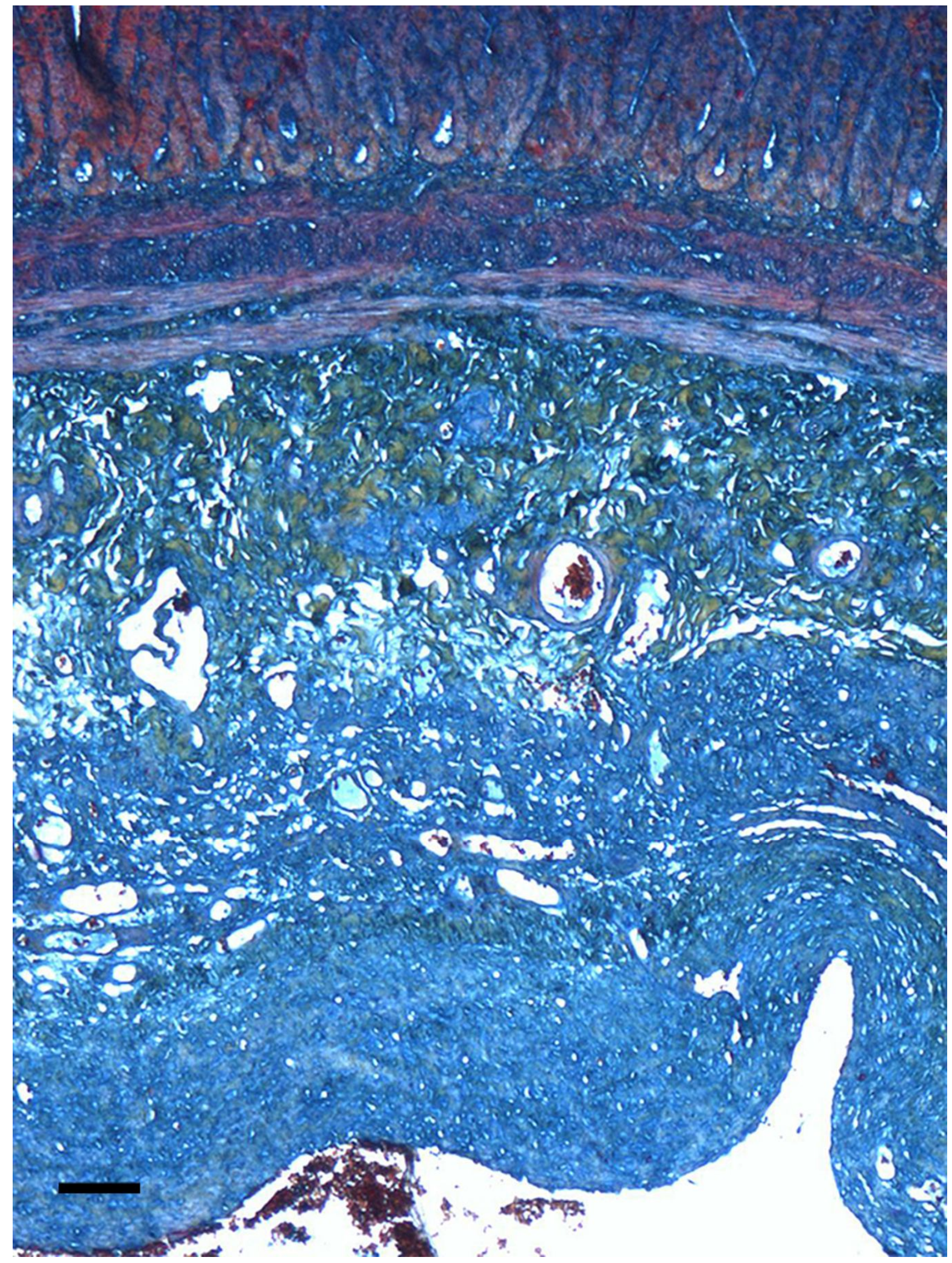


Figure 3 


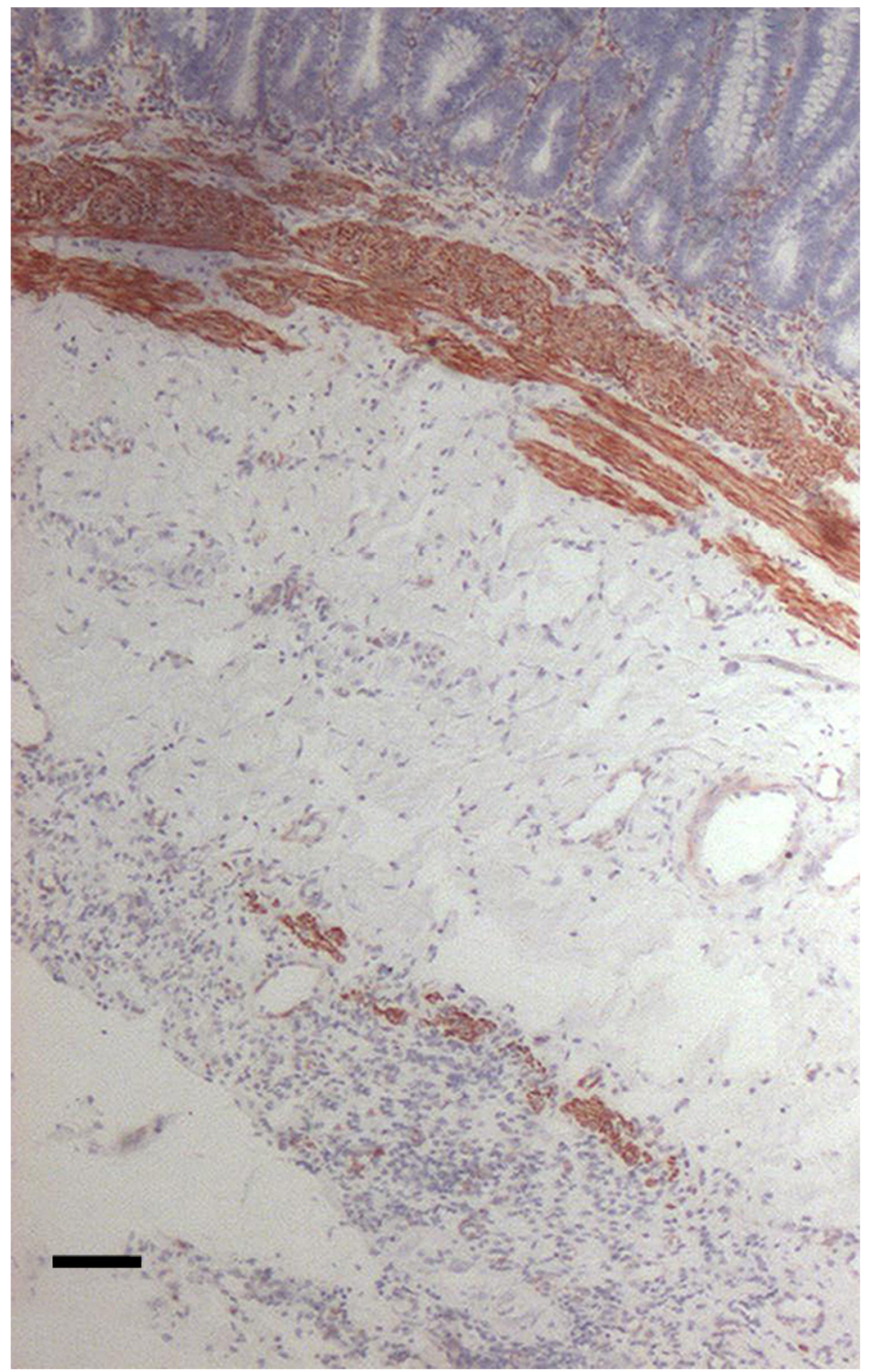




\section{LEGEND TO FIGURES}

Figure 1: Longitudinal and circular muscular layers of the duodenum are completely replaced by collagen and angiogenesis. Multifocal mild lymphoplasmacytic inflammation is also present. Haematoxylin and Eosin stain, 25x. Bar: $25 \mu \mathrm{m}$

Figure 2: Longitudinal and circular muscular layers of the duodenum are partially and totally replaced by collagen, respectively. Masson's Trichrome stain, 25x. Bar: $25 \mu \mathrm{m}$

Figure 3: Variably severe loss of desmin-positive myocytes in longitudinal and circular muscular layers of the duodenum. Anti-Desmin immunohistochemical stain, Carbazole chromogen, M ayer's haematoxylin contrast stain, 25x. Bar: $25 \mu \mathrm{m}$ 